\title{
Analysis of consumer preferences when choosing wine
}

\author{
Viktoriia Lutskova, Irina Martirosyan, Larysa Krupytska
}

\author{
Odesa National Academy of Food Technologies, Odesa, Ukraine
}

\section{Keywords: \\ Wine \\ Consumer \\ Preference \\ Label \\ Choice}

\section{Article history:}

Received 12.01.2020

Received in revised

form 23.05.2020

Accepted 30.06.2020

\section{Corresponding author:}

Viktoriia

Lutskova

E-mail:

ostapenkoviktoriya7@ gmail.com

DOI: $10.24263 / 2310-$

1008-2020-8-1-15

\section{Abstract}

Introduction. The peculiarities of consumer behavior when choosing wine were investigated in current work, that had been dictated by the need to identify preferences for the implementation of effective product policy.

Materials and methods. The research is based on information of a survey conducted using the questionnaire, which consisted of two parts: the personality questions about participants, including their gender, age, income level, social status, and directly the questions about choice of a wine bottle with answer options. The conjunction tables and the $\chi^{2}$ criterion were used to determine statistical correlations between factor and result parameters.

Results and discussion. Taking into account the various characteristics of the wine, including its economic, technological, ampelographic components, as well as the appearance of the bottle and the beverage label, significantly influence the consumers of different social statuses. Thus, women and men with diverse family status differ in the choice of wine, given the grape variety from which it was made, while other quality characteristics of wine is not critically influential. Therefore, consumers with various income levels choose wines of different price categories, the organoleptic properties of which they consider unique. However, the price of wine and its gastronomic attributes are statistically significant for people aged from 18 to 50 that prove the difference among preferences of generations. Also women aged from 25 to 35 with income level higher than 200 American dollars ready to buy souvenir wine bottle.

In addition regardless of marital status, survey participants buy wines at all proposed places of sale, but ones who have higher level of income prefer wine specialized stores. However, married people largely choose wines for holidays, gastronomic pleasure or for medicinal purposes, because wine is enriched by antioxidants, vitamins and has relatively low calorie content. Respondents aged more 35 are also buy wine at the aforementioned shops or directly from the wineries, which may be related to greater experience when choosing alcoholic beverages. Most respondents choose wines whose label is simple and understandable, especially with the image of the winery, a grape cluster, because it demonstrates the production of wine, its place of origin. Moreover, most consumers prefer to add information on the label about the combination of wine with certain products and tend to buy wine, the bottle of which is standard 0,75 $\mathrm{dm}^{3}$.

Conclusions. The criteria of choosing a wine, its quality properties and the choice of purchase place differs among consumers with different personal characteristics, which has the practical importance in order to develop the effective marketing, taking into account the preferences of the population. 


\section{Introduction}

Nowadays the choice of wine for most consumers is the whole philosophy: from aesthetics to taste. After all, the modern consumer wants to buy not only the item of goods, but also a product evoking positive emotions, which depend on the taste properties of wine as well as visual images.

In recent years in Ukraine much attention has been paid to the aesthetic properties of packaging, including design and information expressiveness. This fact is related to not only with cultural development, but also with increasing of the export potential of wines to the European countries. The visual attributes form the wine brand and product sales culture: inform about a value, national and family traditions, current fashion, style trends and others.

Many scientists, including Verneau F. [1], Shane E. [2], A. Sobchak [3], O. Teletov [4], O. Ganotska [5], who had studied the factors influencing the consumer's choice of wine and determined the importance of visual perception of bottle design and expressive labels, color solutions and decoration, their influence on consumer emotions. The goal factors that mostly impact on consumer choice had been defined by researchers. Among them are the region of wine origin [6-10], the brightness of the label, brand and grape variety [11-17]. It should be noted that the trend of "competent consumer" and the role of informativeness of goods including its sufficiency, reliability and accessibility develop today. Also scientists have established the importance of demographic factors affecting the choice of consumers, specifically, age characteristics, income and employment, consumption needs $[11,13,18$ 26].

The national factor and mentality cannot be ignored, as each country has its own rules and traditions for choosing wine. Aspasia Vlachwei in her work [27] has analyzed data (surveys of respondents) from different countries of the world and the main factors influencing the behavior of consumers of wines. Based on the results of the surveys, it can be stated that opinions differ significantly among countries [28-35]. In our view, this fact can be only explained by culture, traditions and national characteristics.

Taking in consideration the above, the aim of article was to determine the consumer preferences of Ukrainians lived in Odessa and to identify the main factors that influence the choice of wine.

\section{Materials and methods}

The objects of research were the peculiarities of consumer behavior when choosing wine in Ukrainian city - Odesa. Should be noted that today Odesa region possesses the biggest areas of vineyards in Ukraine that's why the determination of consumer preferences have the practical significance for wine producers, technologists, marketers.

Methodology. The survey was attended by 61 people aged 18 to 55 (50 and more), including 18 male and 43 female lived in Odessa, Ukraine in the end of March 2020. The time of this research has been chosen not by chance to exclude other influencing factors when choosing a wine, including the nearest holidays or celebrations.

To determine the preferences of consumers when choosing a wine bottle, a questionnaire was created, which was conditionally divided into two parts: questions about gender, age, family status, and the rate of respondent wages, and directly a question regarding the choice of a wine bottle with answer variants. Factors influencing consumer wine choice and offered reasons of a wine purchase, general places of a wine buying were proposed to answer in our questionnaire. The another part of our survey consisted of questions related to design, appearance of label and forms of a wine bottle in order to determine the significant 
level of its impact on consumer preferences. In order to characterize the exact consumer preference of label we offered the six different pictures of existing wine label: 1 . Men on black-and-white paper; 2. Picture in the baroque style with golden lines; 3. An extraordinary label with black lines; 4. Classical wine label with winery and grapes; 5. Wine label with fillwords (Hungarian crosswords); 6. All information about wine was on packing paper.

The correlation between factor and result attributes was calculated using the conjugation tables and the $\chi 2$ criterion. Two-way ANOVA was utilized to determine influence of gender, age, family status and average wage per month on separate questions that also play role when choosing of a wine bottle.

Figures were created using Microsoft Excel, the questionnaire was developed by Google forms.

The average ratio of the exchange rate of 1 American dollar to the Ukrainian national currency was 27,6 Ukrainian hryvnia at the time of research conducting and article writing.

\section{Results and discussion}

\section{General factors influencing consumer wine choice}

Results of four factors including gender, age, family status and average wage per month of consumers show that they quite significantly differ towards wine choice taking into account its diverse characteristics (Table 1).

Significance level of factors influencing consumer wine choice

Table 1

\begin{tabular}{|c|c|c|c|c|c|c|c|c|}
\hline \multirow[t]{2}{*}{$\begin{array}{c}\text { Answer } \\
\text { variants/Factors }\end{array}$} & \multicolumn{2}{|c|}{ Gender } & \multicolumn{2}{|c|}{ Age } & \multicolumn{2}{|c|}{ Family status } & \multicolumn{2}{|c|}{$\begin{array}{c}\text { Average wage } \\
\text { per month }\end{array}$} \\
\hline & $p$ & $\chi^{2}$ & $p$ & $\chi 2$ & $p$ & $\chi^{2}$ & $p$ & $\chi 2$ \\
\hline $\begin{array}{l}\text { Grape variety, } \\
\text { producer country }\end{array}$ & $* *$ & 10,370 & $\mathrm{n} / \mathrm{s}$ & 4.040 & $* *$ & 9.993 & $\mathrm{n} / \mathrm{s}$ & 6.423 \\
\hline $\begin{array}{l}\text { Organoleptic } \\
\text { properties }\end{array}$ & $\mathrm{n} / \mathrm{s}$ & 0.126 & $\mathrm{n} / \mathrm{s}$ & 5.417 & $*$ & 8.736 & $*$ & 12.239 \\
\hline $\begin{array}{l}\text { Aesthetic } \\
\text { properties of the } \\
\text { bottle design }\end{array}$ & $\mathrm{n} / \mathrm{s}$ & 0.146 & $* *$ & 11.876 & $\mathrm{n} / \mathrm{s}$ & 2.691 & $\mathrm{n} / \mathrm{s}$ & 1.743 \\
\hline Price, sales & $\mathrm{n} / \mathrm{s}$ & 0.329 & $* *$ & 37.225 & $* *$ & 21.763 & $* *$ & 15.412 \\
\hline $\begin{array}{l}\text { Gastronomic } \\
\text { preferences }\end{array}$ & $\mathrm{n} / \mathrm{s}$ & 1.792 & $* *$ & 17.184 & $\mathrm{n} / \mathrm{s}$ & 3.104 & $\mathrm{n} / \mathrm{s}$ & 6,020 \\
\hline Advertising & - & - & - & - & - & - & - & - \\
\hline
\end{tabular}

Note: $\mathrm{n} / \mathrm{s}-$ not significant; * - significant at $p<0,05 ; * *$ - significant at $p<0,01$

According to information published in previous studies [8, 11, 13] sensory properties of wine are the main factors that impact on consumer preference. Wine organoleptic attributes were counted practically equally between genders and ages of Ukrainian consumers in our study. But depending on family status and average wage per month respondents divided with significance level of $\mathrm{p}<0,05$ that perhaps due to various social status, influence and inheritance of habits from other members of family. Also such 
fact can be explained by no ordinary wine choices for married and unmarried people with average wage per month more than 250 American dollars. The price is substantially affected on consumer purchase [3] and proved by our observations. Significance level of $p<0,01$ was indicted between wine price situation and age, family status and average wage per month of respondents without taking account gender.

It is remarkable that correlation between genders of different consumers towards grape variety are statistically significant $(p<0,01)$. In accordance with our investigations, most women buy a wine depending on the grape variety and country of production, which in turn proves that female reads the information on a wine bottle label more carefully [3]. People with various average wages per month and ages are not significantly different among themselves when they purchase wines produced from the exact grape variety or wine country that unfortunately means the low wine culture and interest for Ukrainians. The age of respondents was determined statistically significant towards the aesthetic properties of the bottle design and gastronomic preferences that is correct for none typical points of views related to shape, label colours of wine bottles, as well as pairs of wine and food between people aged from 18 to 50 and more $(p<0,01)$. Advertising was proposed as one of answer variants which can influence consumer wine choice. But none of survey participants chose the advertising that means wine is not popular beverage in Ukrainian community or perhaps the promotion is not needed for it.

Place of a wine purchase. Nowadays a place to buying wine plays one of main role due to improving of wine culture worldwide $[17,20]$. Besides general locations people can purchase a wine at different wine festivals or trade fairs and remotely using home delivery. According to results presented in Table 2, Ukrainians shop basically in supermarkets and wine boutiques, and rarely - directly from the winery or make wine by own way.

Table 2

Significance level of factors influencing a place of a wine purchase

\begin{tabular}{|l|l|l|l|l|l|l|l|l|}
\hline \multirow{2}{*}{$\begin{array}{l}\text { Answer variants } \\
\text { /Factors }\end{array}$} & \multicolumn{3}{|l|}{ Gender } & \multicolumn{2}{l|}{ Age } & \multicolumn{2}{l|}{ Family status } & \multicolumn{2}{l|}{$\begin{array}{l}\text { Average wage } \\
\text { per month }\end{array}$} \\
\cline { 2 - 10 } & $\boldsymbol{p}$ & $\boldsymbol{\chi 2}$ & $\boldsymbol{p}$ & $\boldsymbol{\chi 2}$ & $\boldsymbol{p}$ & $\boldsymbol{\chi 2}$ & $\boldsymbol{p}$ & $\boldsymbol{\chi 2}^{\mathbf{2}}$ \\
\hline Supermarket & $*$ & 5,428 & $\mathrm{n} / \mathrm{s}$ & 6,750 & $\mathrm{n} / \mathrm{s}$ & 5,390 & $\mathrm{n} / \mathrm{s}$ & 8,368 \\
\hline $\begin{array}{l}\text { Wine shop, wine } \\
\text { boutique }\end{array}$ & $\mathrm{n} / \mathrm{s}$ & 0,283 & $* *$ & 14,432 & $\mathrm{n} / \mathrm{s}$ & 4,982 & $*$ & 11,638 \\
\hline $\begin{array}{l}\text { Directly from the } \\
\text { winery }\end{array}$ & $\mathrm{n} / \mathrm{s}$ & 1,127 & $* *$ & 12,850 & $\mathrm{n} / \mathrm{s}$ & 4,201 & $\mathrm{n} / \mathrm{s}$ & 4,170 \\
\hline Own production & $\mathrm{n} / \mathrm{s}$ & 0,417 & $\mathrm{n} / \mathrm{s}$ & 0,617 & $\mathrm{n} / \mathrm{s}$ & 4,325 & $\mathrm{n} / \mathrm{s}$ & 5,621 \\
\hline
\end{tabular}

Note: $\mathrm{n} / \mathrm{s}$ - not significant; $*$ - significant at $\mathrm{p}<0,05 ; * *$ - significant at $\mathrm{p}<0,01$

The proposed answer variants were detected unimportant for respondents with different family status. But such factor as average wage per month of consumers influence choice of a wine place namely wine specialized shops and boutiques that can be explained by various rates of wages and willingness to buy a wine with different price categories. Also the correlation between survey participants with various ages and abovementioned wine places were indicated significant clarifying human education and perhaps experience in a wine choice likewise buying of wine directly from the winery. Based on previous research [20], women may shop spontaneously and men purposefully procure goods in supermarkets that obtained results were showed. 


\section{Factors influencing offered reasons of a wine purchase}

Noteworthy is that the antecedent analysis identified no significance between people with different family status and their choice of a wine place of purchase, but in accordance with Table 3 this factor influences reasons of a wine purchase. It appears probable that family traditions and holidays, as well as feast are the reasons to buy a wine for people with different civil status [27]. Also consumers aged from 18 to 50 differed in case of a wine purchase for holidays and respondents with diverse rates of wages - for gastronomic pleasure. No significance was detected between participants of different gender when they buy a wine according to proposed reasons.

Table 3

Significance level of factors influencing offered reasons of a wine purchase

\begin{tabular}{|c|c|c|c|c|c|c|c|c|}
\hline \multirow{2}{*}{$\begin{array}{l}\text { Answer } \\
\text { variants } \\
\text { /Factors }\end{array}$} & \multicolumn{2}{|c|}{ Gender } & \multicolumn{2}{|c|}{ Age } & \multicolumn{2}{|c|}{ Family status } & \multicolumn{2}{|c|}{$\begin{array}{c}\text { Average wage } \\
\text { per month }\end{array}$} \\
\hline & $p$ & $\chi^{2}$ & $p$ & $\chi^{2}$ & $p$ & $\chi^{2}$ & $p$ & $\chi^{2}$ \\
\hline $\begin{array}{l}\text { Gastronomic } \\
\text { pleasure }\end{array}$ & $\mathrm{n} / \mathrm{s}$ & 1.641 & $\mathrm{n} / \mathrm{s}$ & 3.438 & $*$ & 7.579 & ** & 16.716 \\
\hline Holidays & $\mathrm{n} / \mathrm{s}$ & 0.212 & $* *$ & 13.195 & $* *$ & 9.556 & $\mathrm{n} / \mathrm{s}$ & 3.741 \\
\hline $\begin{array}{l}\text { Therapeutic } \\
\text { goals }\end{array}$ & $\mathrm{n} / \mathrm{s}$ & 0,240 & $\mathrm{n} / \mathrm{s}$ & 3.998 & $*$ & 6.456 & $\mathrm{n} / \mathrm{s}$ & 2,019 \\
\hline No matter & $\mathrm{n} / \mathrm{s}$ & 0,116 & $\mathrm{n} / \mathrm{s}$ & 2,573 & $\mathrm{n} / \mathrm{s}$ & 4,020 & $\mathrm{n} / \mathrm{s}$ & 3,554 \\
\hline
\end{tabular}

Note: $\mathrm{n} / \mathrm{s}$ - not significant; $*$ - significant at $\mathrm{p}<0,05 ; * *$ - significant at $\mathrm{p}<0,01$

Results of ANOVA analysis proved that people of different gender, age and average wage per month are differentiated towards a wine buying taking into account its label (table 4).

Significance of a wine label

Table 4

\begin{tabular}{|l|l|l|l|l|}
\hline Answer variants /Factors & Gender & Age & $\begin{array}{l}\text { Family } \\
\text { status }\end{array}$ & $\begin{array}{l}\text { Average wage } \\
\text { per month }\end{array}$ \\
\hline Buying a wine I read its label & $*$ & $*$ & $\mathrm{n} / \mathrm{s}$ & $*$ \\
\hline
\end{tabular}

Note: $\mathrm{n} / \mathrm{s}$ - not significant; $*$ - significant at $\mathrm{p}<0,05 ; * *$ - significant at $\mathrm{p}<0,01$

Among the proposed answers in the questionnaire, most respondents chose the answer that they always read the information on a wine label, but especially women aged 25-35 are more attentive to the text. Moreover, people who earn more than 280 American dollars choose a wine according to label and also require consistency between quality of wine and its price. Most people between the ages of 18 and 25 years old were found who never or rarely read the information on the wine label which indicates non-acquaintance of wine culture. Family status of respondents was determined insignificant in the context of a label reading. 


\section{Label design}

Consumers were proposed to answer which label design they prefer [36, 37]. Based on Figure 1, survey participants ready to buy a wine with light label design which is understandable and clear for them. However, the second big percent of answers was defined belonged to group who has never thought about it, meaning a label design is not remarkable.

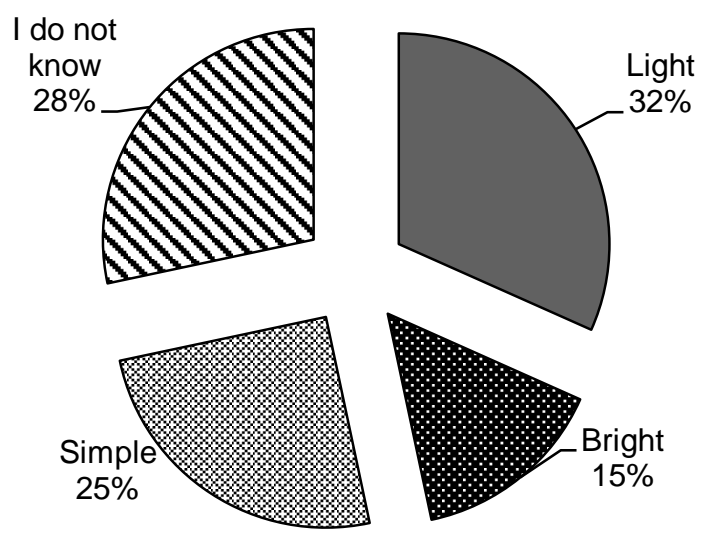

Figure 1. Consumer preference on label design

Analysis of label pictures acknowledged that the most of respondents would rather a simple label with image of winery and grapes. Such fact may also explain subconscious choice of consumers when they see things associable with wine [15]. The labels which illustrated men on black-and-white paper, picture in the baroque style with golden lines and one where all information about wine has been written on packing paper were chosen by the same number of survey participants. The label pictures with fillwords (Hungarian crosswords) and black lines obtained the lowest percent of choice -5 and $2 \%$ of total number of interviewed that perhaps demonstrates about consumer mind towards uselessness of an unusual label design for a quality wine.

Evaluating the label influence on wine choice included the question about adding of other information to the existing one on the label. $59 \%$ of respondents were unanimous in adding of information on the combination of wine with various products. Therefore, consumers were interested in processes of wine technology and indicators forming the wine price. Honest wine composition was written by 2 respondents of survey on line «Add your answer» that can be sign of their incredulity regarding winemaking. 


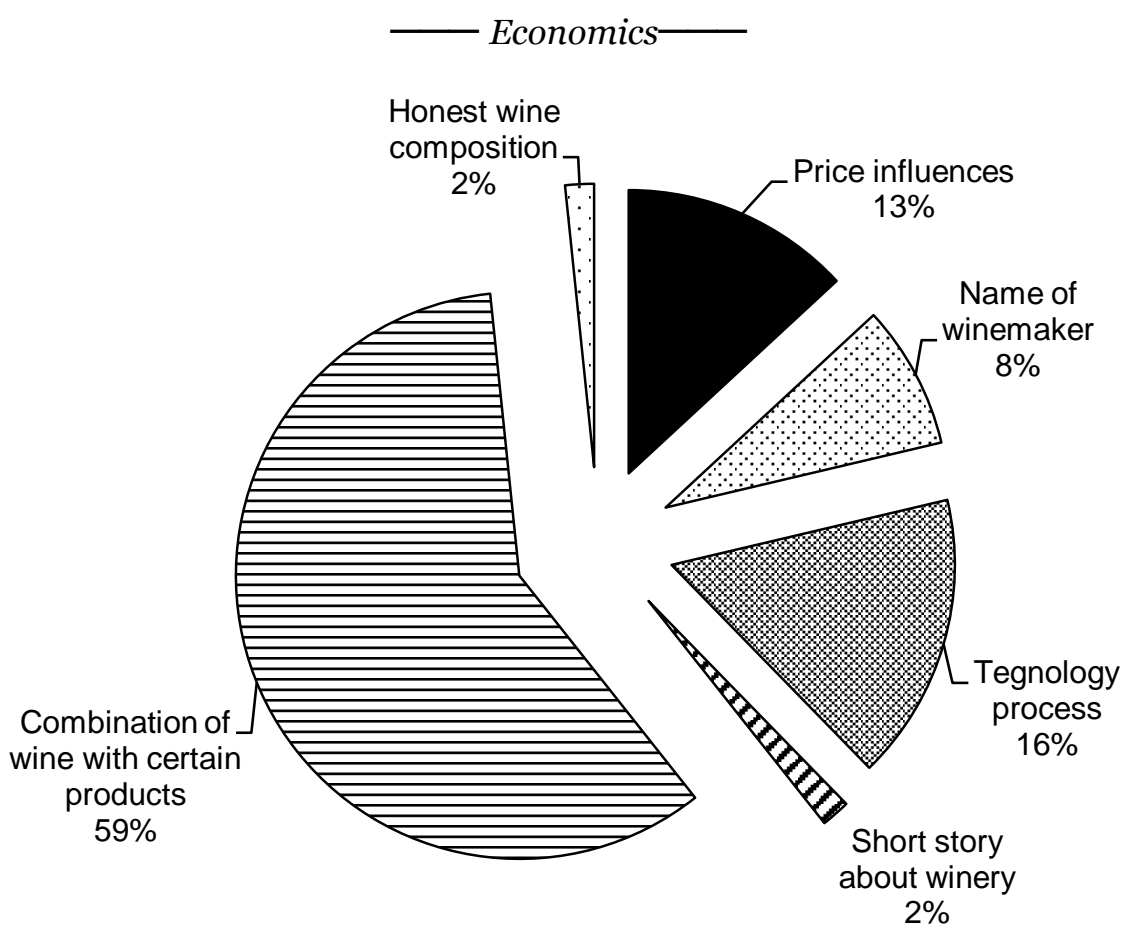

Figure 2. Consumer desired information to add

\section{Wine bottle}

Souvenir wine bottle can be present for any celebrating and thing of art. For this reason, many wine producers present the own alcoholic beverages bottling in untypical tares [30, 31]. According to data in table 5, correlation between age and family status of consumers and their readiness to buy souvenir wine bottle were not identified significant. But gender of respondents and their average wage per month showed discrepancy among its groups. It is no wonder that most women choose souvenir bottles who have average wage per month of 200-300 American dollars.

Table 5

Significance of a wine bottle

\begin{tabular}{|l|l|l|l|l|}
\hline Answer variants /Factors & Gender & Age & $\begin{array}{l}\text { Family } \\
\text { status }\end{array}$ & $\begin{array}{l}\text { Average wage } \\
\text { per month }\end{array}$ \\
\hline $\begin{array}{l}\text { Ready to buy souvenir wine } \\
\text { bottle }\end{array}$ & $*$ & $\mathrm{n} / \mathrm{s}$ & $\mathrm{n} / \mathrm{s}$ & $*$ \\
\hline
\end{tabular}

Note: $\mathrm{n} / \mathrm{s}$ - not significant; $*$ - significant at $\mathrm{p}<0,05 ; * *$ - significant at $\mathrm{p}<0,01$

$71 \%$ of Ukrainian who took part in our questionnaire preferred the typical volume of wine bottle $-0,75 \mathrm{dm}^{3}, 18$ and $15 \%-0,5$ and $1 \mathrm{dm}^{3}$ respectively (Figure 3 ). 


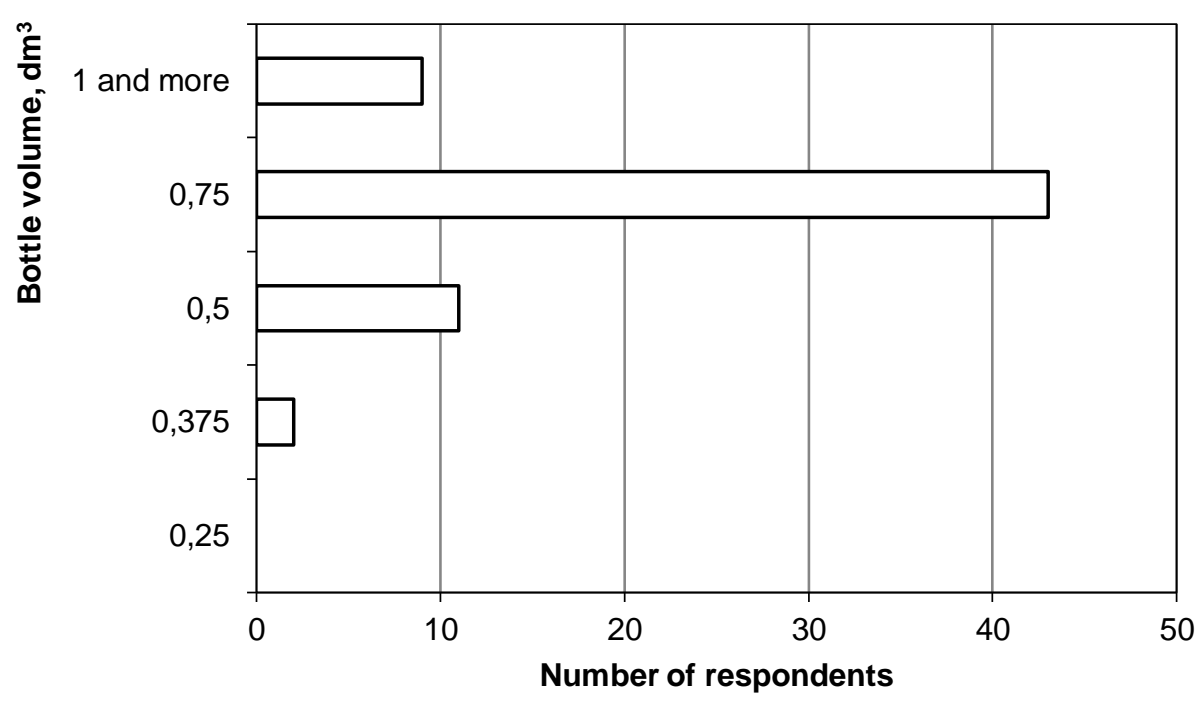

Figure 3. Consumer preference of a wine bottle volume

As a rule, the bigger the volume of a wine bottle, the more expensive it is. Nevertheless, quality wines including premium are poured into bottles of 0,25 and 0,375 $\mathrm{dm}^{3}$ for hotel and catering business that cost more. On the supposition that with due regard for wine price abovementioned bottle volumes are not popular among majority of people.

\section{Conclusion}

Summarizing the results of our research, it can be concluded that today the culture of wine consumption is developed rapidly in Ukraine. And the consumer tends to awareness the product with history and old traditions, because wine plays an important role in the life of the modern man: for some it is tradition and holidays, for others it is special moments of life.

According to results wine and its packaging are considered a unified whole by the consumer, inasmuch as the appearance of the packaging plays an extremely important role in the consumer belief process.

Particular attention needs to be paid to exploring elements such as the design and label of the wine, because namely they encourage the undecided consumer to buy the product.

\section{References}

1. Verneau F., Griffith C. J., Agnoli, L., Capitello R., Begalli D. (2016), Behind intention and behaviour: factors influencing wine consumption in a novice market. British Food Journal, 118 (3), pp. 660-667, DOI: 10.1108/BFJ-05-2015-0181.

2. Shane E., Murad M. and Freeman S. (2018), Factors influencing price premiums of Australian wine in the UK market, International Journal of Wine Business Research, 30 (1), pp. 96-116. https://doi.org/10.1108/IJWBR-02-2017-0009. 
3. Sobchak A.P., Kovalenko S.V. (2013), Rol upakovki v pidvischenni efektivnosti marketingovoyi diyalnosti pidpriemstv, Zbirnik naukovih prats Harkivskogo natsionalnogo pedagogichnogo universitetu imeni G. S. Skovorody, 13, pp. 219-228.

4. Teletov O.S., Shatova V.M. (2014), Upakovka yak ob'ekt innovatsiynogo marketingu, Marketing i menedzhment innovatsiy, 2, pp. 11-20.

5. Ganotska O (2009), Dizayn spozhivchoyi upakovki v ukrayini: Suchasni priyomi ta zasobi, Mistetstvo, istoriya, suchasnist, teoriya, 6, pp. 63-68.

6. Orth U.R., Wolf-McGarry M., Dodd T. H. (2005), Dimensions of wineregion equity and their impact on consumer preferences, Journal of Product \& Brand Management, 14(2), pp. 88-97.

7. Rodriguez Santos C., Cervantes Blanco M., Gonzalez Fernandez A. (2006), Segmenting wine consumers according to their involvement with appellations of origin, Brand Management, 13 (4-5), pp. 300-12.

8. Casini L., Corsi A.M., Goodman S. (2009), Consumer preferences of wine in Italy applying best-worst scaling, International Journal of Wine Business Research, 21(1), pp. 64-78.

9. Chengyan Yue, Marette S., John C.B. (2006), How to Promote Quality Perception in Wine Markets: Brand Advertising or Geographical Indication? Working Paper 06-WP 426August 2006 Center for Agricultural and Rural Development Iowa State University Ames.

10. Felzensztein C., Hibbert, S. Vong G. (2004), Is the country of origin the fifth element in the marketing mix of imported wine? A critical review of the literature, Journal of Food Products Marketing, 10(4), pp. 73-84.

11. Barber N., Ismail J., Dodd T. (2008), Purchase attributes of wine consumers with low involvement. Journal of Food Products Marketing, 14(1), 69-86

12. Rocchi B., Stefani G. (2005), Consumer's perception of wine packaging: case study, International Journal of Wine Marketing, 18(1), pp. 33-44.

13. Sherman, Scott and Tracy Tuten, (2011), Message on a bottle: the wine label's influence, International Journal of Wine Business Research, 23(3), pp. 221-234.

14. Gabor O., Skrygun N., Mirochnyk V. (2015), Brand-coloring in the formation of visual symbolism brand, Stredoevropsky vestnik pro vedu a vyzkum, 16 (3), pp 5-9, DOI: 10.17686/sced_2015-188868

15. Batt P., Dean A., (2000), Factors influencing the consumer's decision, Australian and New Zealand Wine Industry Journal, 15(4), pp. 34-41.

16. Brunner T., Siegrist M., (2011), Lifestyle determinants of wine consumption and spending on wine, International Journal of Wine Business Research, 23(3), pp. 210-220.

17. Lockshin L., Hall J. (2003), Consumer purchasing behaviour for wine: what we know and where we are going, Paper presented at International Wine Marketing Colloquium, Adelaide. pp. 190-203.

18. Lockshin L., Pascale Q., Spawton T., (2001), Segmentation by involvement or Nationality for Global Retailing: A Cross National Comparative Study of wine Shopping Behaviours, Journal of Wine Research, 12(3), pp. 223-236.

19. Henley C., Deborah C., Fowler J.Y, Betty L.S., Ben K.G. (2011), Label design: impact on millennials' perceptions of wine, International Journal of Wine Business Research, 23(1), pp. 7-9.

20. Hollebeek L., Jaeger S., Brodie R., Balemi A. (2007), The influence of involvement on purchase intention for new world wine, Food Quality and Preference, 18, pp. 1033-1049.

21. Galati A., Tinervia S., Tulone A., Crescimanno M., Rizzo G. (2018). Label style and color contribution to explain market price difference in Italian red wines sold in the Chinese wine market, Journal of International Food \& Agribusiness Marketing, 30(2), 175-190.

22. Geraghty S., Torres A. (2009), The Irish wine market: a market segmentation Study, International Journal of Wine Business Research, 21(2), pp. 143-154. 
23. Goodman S., L. Lockshin E. Cohen, J. Fensterseifer H. Ma, F. d'Hauteville L. Sirieixf U. Orth, L. Casini, A. Corsi, S. Jaeger, P. Danaher, R. Brodie, J. Olsen, L Thach, J.-P. Perrouty (2008), International Comparison of Consumer Choice for Wine: A Twelve Country Comparison» 4th International Conference of the Academy of Wine Business Research, Siena, 17-19 July, 2008.

24. Öztürk B., Ertamay S. İ. (2019), Wine bottle design thinking modelling: An analysis of local wine brands within Urla vineyard road. In BIO Web of Conferences (Vol. 15, p. 03014). EDP Sciences.

25. Vecchio R., Annunziata A., Mariani A. (2018), Is more better? Insights on consumers' preferences for nutritional information on wine labelling, Nutrients, 10(11), 1667, DOI: 10.3390/nu10111667.

26. Martinez-Carrasco Martinez, L., Brugarolas Molla`-Bauza` M., Del Campo Gomis, F.J Martinez Povera, A. (2006), Influence of purchase place consumption frequency over quality wine preferences, Food Quality and Preference, 17, pp. 315-27.

27. Vlachvei A., (2011), Faktory, yaki vlyvaiut na povedinku spozhyvachiv ta pokuptsiv vyna. Zhurnal yevropeiskoi ekonomiky, 10(4), pp. 428-445.

28. Mc Cutcheon E., Bruwer J., Li E. (2009), Region of origin and its importance among choice factors in the wine-buying decision making of consumers. International Journal of Wine, 21(3), pp. 212-234.

29. Mueller K., Lockshin D. (2008), How important is wine packaging for consumers? On the reliability of measuring attribute importance with direct verbal versus indirect visual methods, 4th International Conference of the Academy of Wine Business Research, Siena, 17-19 July, 2008.

30. Sigala M. (2007), WEB 2.0 in the tourism industry: A new tourism generation and new ebusiness models, Ecoclub, 90, pp. 5-8.

31. Silayoi P., Speece M. (2007), The importance of packaging attributes: a conjoint analysis approach, European Journal of Marketing, 41(11/12), pp.1495-1517.

32. Salem M. (2018), Effects of perfume packaging on Basque female consumers purchase decision in Spain, Management Decision, 56(8), pp. 1748-1768. , DOI: 10.1108/MD-042017-0363.

33. Tiefenbacher J. P., \& Townsend C. (2020), The Semiofoodscape of Wine: The Changing Global Landscape of Wine Culture and the Language of Making, Selling, and Drinking Wine, Handbook of the Changing World Language Map, pp. 4103-4145.

34. Viot C., Passebois-Ducros J. (2010), Wine brands or branded wines? The specificity of the French market in terms of the brand, International Journal of Wine Business Research, 22(4), pp. 406-422.

35. Wansinsk B., Cordua G., Blair E., Payne C., Geiger S. (2006), Wine promotions in restaurants. Do beverage sales contribute or cannibalize?, Cornell Hotel and Restaurant Administration Quarterly, 47, pp. 327-36.

36. Asmalovskij Alexandr, Sadilek Tomas (2016), Food quality perception in the Czech Republic: trial study results, Ukrainian Food Journal, 5(1), pp. 186-194

37. Dumitru Mnerie, Liviu Gaceu, Oleksii Gubenia, Mark Shamtsyan, Adriana Birca, Gabriela Victoria Mnerie (2016), Comparative study on the evolution of the food labeling quality in some countries from the Black Sea region, Journal of Hygienic Engineering and Design, 14, pp. $60-65$. 